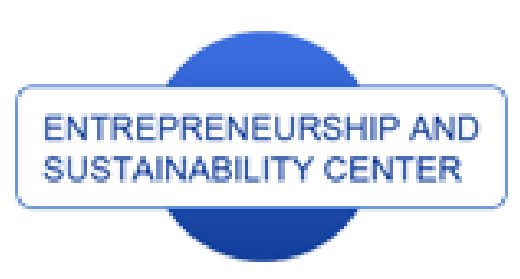

Publisher
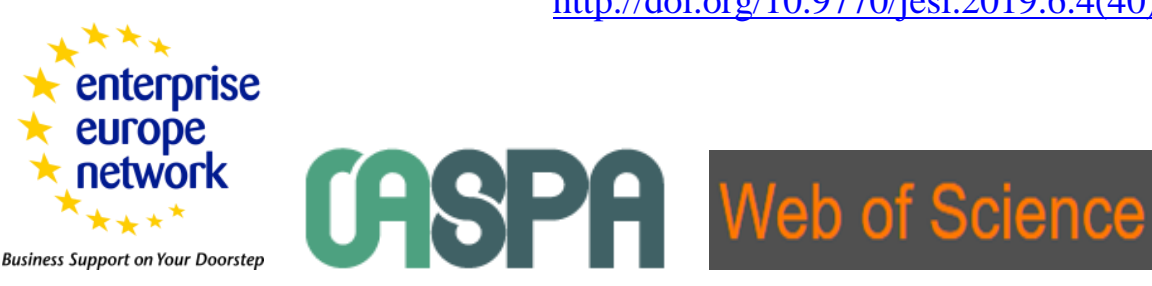

1 Clarivate Analytics

\title{
THE ROLE OF FOREIGN DIRECT INVESTMENT IN THE ECONOMY OF SLOVAKIA*
}

\section{Judita Táncošová}

\begin{abstract}
University of Economics and Management of Public Administration in Bratislava, Furdekova 16, 85104 Bratislava, Slovak Republic
\end{abstract}

E-mails: judita.tancosova@vsemvs.sk

Received 10 December 2018; accepted 15 April 2019; published 30 June 2019

\begin{abstract}
In the paper, we point out the role of FDI in the Slovak economy, analyze their status in the period from 2010 to 2015 , suggest their regional and branch aspect. FDI is an effective form of international business that complements lack of internal resources and contributes to economic growth. As competition of FDI is very strong, it is important to create appropriate economic, political and legislative conditions that the economy is capable of creating for foreign investors. The state of FDI in the Slovak economy has been gradually increasing since 2010, but its large sectoral and regional imbalances appear to be unfavorable. The impact of FDI on GDP development indicates that each FDI unit contributes to economic growth, respectively GDP growth; it affects employment and contributes to the solution of unemployment. The problems of FDI in the Slovak economy are one-sided positioning in the automotive industry and at the same time their location in the developed regions, i.e. in the area of Western Slovakia.
\end{abstract}

Keywords: foreign direct investment; portfolio investment; economic growth; GDP; unemployment; regional development

Reference to this paper should be made as follows: Táncošová, J. 2019. The role of foreign direct investment in the economy of Slovakia, Entrepreneurship and Sustainability Issues 6(4): 2127-2135. http://doi.org/10.9770/jesi.2019.6.4(40)

* The paper is the output of a scientific project IGA 3/2017 of a scientific project IGA no. 3/2017 „Development of international business and international management in the conditions of globalization" (Funder: VSEMvs IGA VSEMvs, i.e. School of Economics and Management in Public Administration)
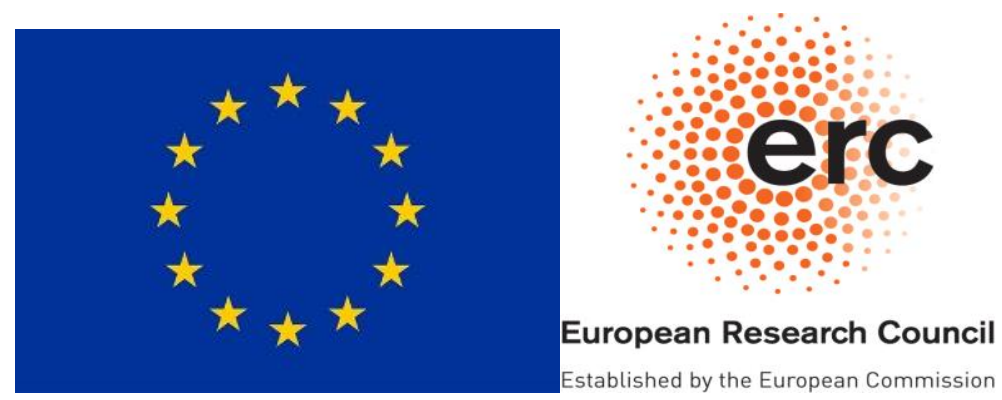


\section{ENTREPRENEURSHIP AND SUSTAINABILITY ISSUES}

ISSN 2345-0282 (online) http://jssidoi.org/jesi/

2019 Volume 6 Number 4 (June)

http://doi.org/10.9770/jesi.2019.6.4(40)

JEL Classifications: E22, F21, F43

\section{Introduction}

Foreign direct investment (FDI) is generally regarded as an effective form of international economic relations and international business and can directly contribute to a significant increase in investment resources in each economy. The problem of individual economies is the lack of internal resources and therefore FDI is an indispensable complement to them, which increases economic growth, affects employment, improves technological management know-how and positively affects other areas of the economy. It is evident that in FDI companies, for example, higher labor productivity per worker, FDI bring more effective operation of companies and regions, and also indirectly in the form of spill-owers effects, i.e., in the form of positive externalities. The competition for FDI is very strong and limited, so it is important to create appropriate economic, political and legislative conditions to attract foreign investors and increase their inflow. Even Slovakia is a country that needs external resources and therefore needs to improve its investment attractiveness.

Many authors deal with this issue from different perspectives, pointing out the role of FDI in the economy as well as the form of realization. The major subjects through which FDI enter the economy include multinational corporations, their activities and their impact on the economy are both positive and negative as reported by the authors, e.g. R.E. Caves (2007), J.H. Dunning (2012) and S. Ferenčíková (2013), M. Tvaronavičienė et al. 2018, Z. Zeibote et al. 2019. FDI is significant in terms of overwhelmingly positive consequences. The role of vertical and horizontal foreign investment on the example of several economies and the intensification of entrepreneurial activities emphasize, for example, J. Hardy, M. Pollakova Fifekova and M. Sass (2011). From Slovak authors who are investigating FDI in terms of their impact on economic growth, unemployment, other macroeconomic indicators, resp. their influence on the safety of the population or economy are T. Dudáš (2010), M. Fabuš (2014, 2015), M. Fabuš, M. Csabay (2018), L. Shuyan, M. Fabuš 2019; M. Kováč (2016) and L. Kabát, S. Filip and L. Filipová (2016).

Another possible approach to investigating FDI is the decision of foreign investors to locate them in a particular economy or region. In this context, it is necessary to examine the investment attractiveness of the economy, the quality of the business environment, and to observe the individual determinants affecting the decisions of foreign investors M. Fabuš (2017), M. Lincényi and M. Fabuš (2017). The entry of foreign investments also affect socioeconomic relations in economies, for example by influencing the labor market, employment, and often lead to the growth of migratory movements, especially in economies that imply economically more favorable conditions. These facts are reflected, for example in I. Dudová and S. Polonyová (2017), further article of I. Dudová and V. Stanek (2016).

In emphasizing the role of FDI in the economy, it is necessary to see their impact on regional development and the reduction of regional disparities. It can be said that the entry of a major investor increases regional GDP, increases employment and improves the overall conditions of business entities in terms of improving managerial skills, organizational structure, qualification and education of labor forces, and so on. K. Stachová and Z. Stacho (2016, 2017), but also V. Gozora and M. Hudáková (2014).

The study of the FDI impact on the economy in Slovakia's conditions was based on publications that examine the theoretical approaches to FDI, their practical implementation from a regional and sectoral point of view and their impact on selected macroeconomic indicators J. Táncošová and A. Slaný (2004), J. Táncošová and S. Švecová (2012) and J. Táncošová (2012). 


\section{ENTREPRENEURSHIP AND SUSTAINABILITY ISSUES}

ISSN 2345-0282 (online) http://jssidoi.org/jesi/

2019 Volume 6 Number 4 (June)

http://doi.org/10.9770/jesi.2019.6.4(40)

Our intention is to find the answer to the research questions: What is the impact of FDI entry on the economy of Slovakia in the period and do they contribute to economic growth and reduce unemployment? Is it possible to achieve better regional and sectoral directions for the FDI to Slovakia, which are the main causes of this situation in the period under review?

\section{Development of FDI inflow into Slovakia and economic growth}

When we come out from the FDI status to the Slovak economy, we see (Table 1) that there is a slight fluctuation in the development, which means the alternation of the periods with a higher but also lower inflow of FDI. Significantly, the FDI inflow was marked by the time of the last global recession, which affected the behavior of foreign investors whose behavior became more cautious. This period is already over and from 2010 until now there is a gradual increase in the volume of FDI and an overall revival of the movement of long-term capital.

Table 1. Status of FDI to the Slovak economy in 2010 - 2015 (mil. Eur)

\begin{tabular}{|l|c|c|c|}
\hline Years & Equity participation and reinvested capital & Other capital & In sum \\
\hline 2010 & 31,793 & 5,871 & 37,665 \\
\hline 2011 & 34,021 & 6,151 & 40,173 \\
\hline 2012 & 34,131 & 7,648 & 41,779 \\
\hline 2013 & 35,249 & 6,822 & 42,071 \\
\hline 2014 & 34,039 & 6,938 & 40,969 \\
\hline 2015 & 35,917 & 6,347 & 42,265 \\
\hline
\end{tabular}

Source: Based on https://www.nbs.sk/en/statistics/balance-of-payments-statistics/foreign-direct-investment

FDI we mention in the structure the equity participation and the reinvested capital, the other capital and the overall state. Equity participation means monetary and non-monetary investor deposits that are invested in basic capital and include equity-shares. Reinvested earnings are the proportion of direct investors in proportion to the equity participation and other capital includes corporate credit operations.

Economic growth is generally defined as the increase in basic macroeconomic variables over time, and is most often expressed by the increase in Gross Domestic Product (GDP). GDP development is affected by the ability of the economy to make full use of capital and human resources, especially internal. In the absence of internal resources, they are most often supplemented by external, mainly foreign direct investment. In the previous section, we have listed the FDI status in the Slovak Republic since 2010 and we are now showing the development of GDP in the same time period. GDP developments were also influenced by the global economic and financial recession, which was fully reflected in Slovakia in 2009, which led to a lower inflow of FDI and a drop in GDP. In 2008, the level of GDP was 68,322.5 million. EUR and in 2009 it amounted to EUR 63,818.5 million, only $93.4 \%$ (compared to the previous year). From 2010, the recovery and gradual growth of GDP in Slovakia took place. The evolution of selected macroeconomic indicators is shown in Table 2.

Table 2. Development of GDP, GDP/per capita, unemployment in Slovak republic in 2010 - 2015

\begin{tabular}{|c|c|c|c|c|}
\hline Years & $\begin{array}{c}\text { GDP in current } \\
\text { pricesin mil. Eur }\end{array}$ & $\begin{array}{c}\text { Change to the previous year } \\
\text { - index }\end{array}$ & $\begin{array}{c}\text { GDP per capita } \\
\text { in Eur }\end{array}$ & $\begin{array}{c}\text { Unemployement } \\
\text { in \% }\end{array}$ \\
\hline 2010 & 67577,3 & 105,6 & 12450 & 14,4 \\
\hline 2011 & 70327,2 & 104,5 & 13080 & 13,5 \\
\hline 2012 & 72703,2 & 102,9 & 13450 & 14,0 \\
\hline 2013 & 74169,9 & 102,0 & 13700 & 14,2 \\
\hline 2014 & 76087,8 & 102,6 & 14010 & 13,2 \\
\hline 2015 & 78896,4 & 103,7 & 14510 & 11,5 \\
\hline
\end{tabular}

Source: Statistical office of SR $\underline{\text { www.statistics.sk }}$ 
From the point of view of the reached indicators, it can be said that economic growth started to recover in 2010, which was reflected in GDP growth, although in 2011-2012 it was very mild and more or less stagnant. The more favorable development is only happening from 2014, which is maintained until today. This was also reflected in an increase in GDP per capita as well as the gradual decline in the unemployment rate, which fell below $10 \%$ in $2016(9.6 \%)$ and is still decreasing.

Comparing GDP and FDI developments in the Slovak economy, there is a certain correlation between these indicators. We can say that any increase in FDI also results in an increase in GDP (not directly in proportion) and consequently also in the fall in unemployment. Of course, we have to realize that other effects and factors in the economy also have a multiplier and acceleration principle, and their manifestations in the economy show a certain lag rather than directly proportional. From the point of view of conclusions, we can state (in connection with the first research question) that without FDI, the economic growth in Slovakia in individual years could not be achieved, although with some additional effect. This means that each FDI unit has some effects in economic growth, but it will also be reflected in a reduction of unemployment.

\section{Territorial, sectoral and regional aspect of FDI development in Slovakia}

Let us look further at the territorial aspect of FDI development, comparing the baseline for 2010 to 2015, which is the last year with the final data published by the National Bank of Slovakia (hereinafter NBS). We can state that the largest investors were the Netherlands, Austria and Germany. Of the total FDI in 2010 of 37.7 million euro participated in percentage terms respectively: $25.5 \%$, Austria 16.7\%, Germany $12.2 \%$, and Italy $8.4 \%$, Czech Republic 5.8\%, France 5.03\%, Hungary 5.2\% and South Korea 4.2\%. From the total FDI in 2010 (€ 37.7 million), up to $83 \%$ comes from these seven countries. As shown in the figure below, we see FDI in millions EUR and the percentage of largest investors in Slovakia. The graphical representation of the data is shown in Figure 1.

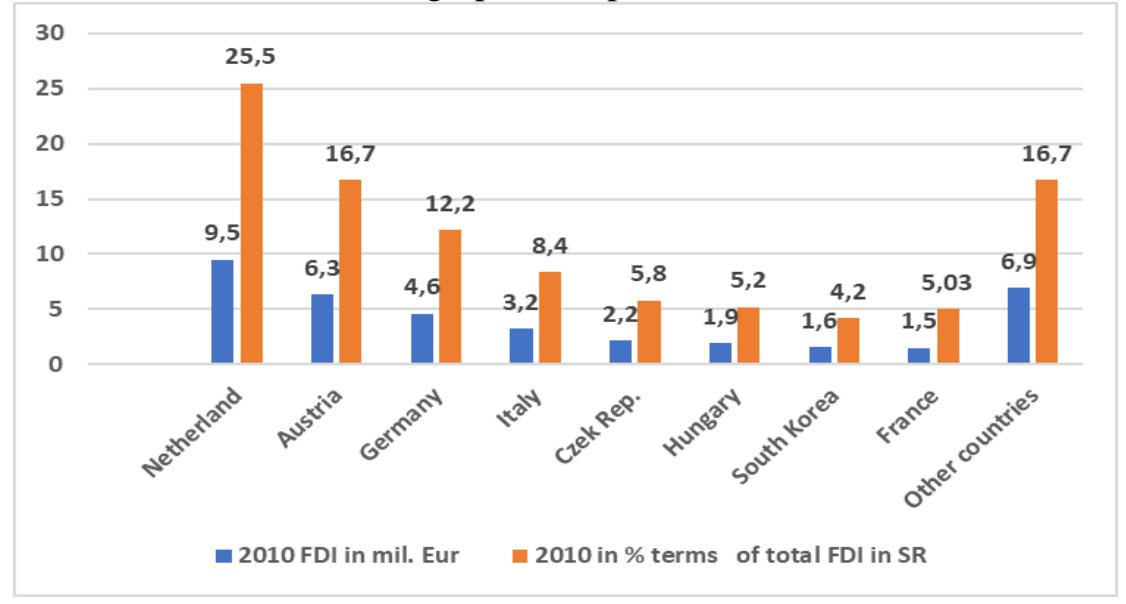

Fig.1. FDI by country of origin in 2010 FDI inward positions in SR/2010/countries

Source: Statistics of the Balance of Payments - $\underline{w w w . n b s . s k}$

In 2015 from the total FDI 42.3 mil. euros were the largest foreign investors in percentage terms in the following countries: the Netherlands 19.6\%, Austria 19.1\%, Czech Republic 9.9\%, Luxembourg 8.5\%, Germany $6.6 \%$, Italy 7.3\%, South Korea 7.1\% and Hungary 5.6\%. Compared to 2010, Luxembourg was among the most significant investors, and the share of traditional countries France and Germany fell. Its 
position has been strengthened by the Czech Republic and South Korea. Of the total FDI in 2015, about $84 \%$ comes from these eight countries. The graphical representation of the data is shown in Figure 2.

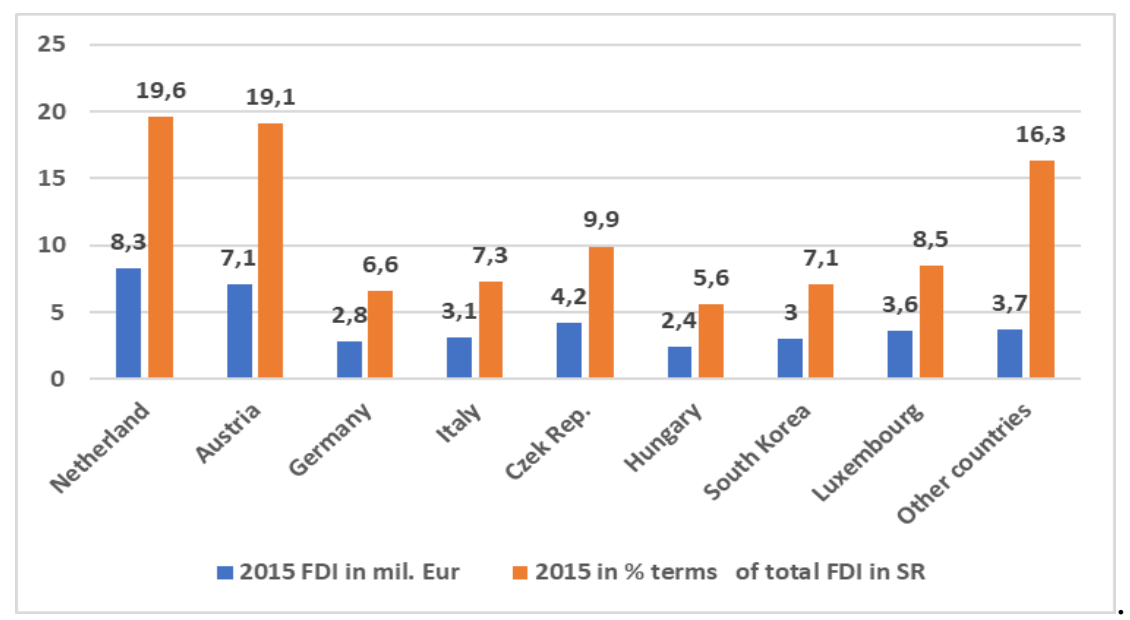

Fig.2. FDI by the country of origin in 2015

FDI inward positions in SR/2015/countries

Source: Statistics of the Balance of Payments - www.nbs.sk

The FDI sectoral trend in 2010 is even more unevenly distributed, and in general, the overall FDI is placed in a relatively small number of industries where industry, financial and insurance, and electricity, gas and service supply have the largest share of the overall FDI they are wholesale and retail. The overview of the sectors with the largest proportion of FDI is shown in Table 3.

Table 3. Status of FDI in SR by economic sectors in 2010 and 2015

FDI inward positions in SR/Economic activity in 2010 and 2015

\begin{tabular}{|c|c|c|c|c|}
\hline Economical sectors & FDI in mil. Eur. & $\begin{array}{c}\text { \% proportion on } \\
\text { whole FDI in 2010 }\end{array}$ & $\begin{array}{c}\text { FDI in mil. Eur. } \\
2015\end{array}$ & $\begin{array}{c}\text { \% proportion on } \\
\text { whole FDI in 2015 }\end{array}$ \\
\hline Industrial production & 12,9 & 34,2 & 14,1 & 33,3 \\
\hline Electricity and gas supply & 5,7 & 15,1 & 1,8 & 4,2 \\
\hline Wholesale and retail & 3,7 & 9,8 & 3,8 & 9,0 \\
\hline Financial and insurance activities & 8,1 & 21,9 & 10,3 & 24,3 \\
\hline Real estate activities & 2,1 & 5,6 & 3,0 & 7,1 \\
\hline Information and communication & 1,6 & 4,2 & 2,2 & 5,2 \\
\hline Expert, scientific and technical activities & 1,4 & 3,7 & 1,5 & 3,5 \\
\hline
\end{tabular}

Source: Statistics of Balance of Payments - www.nbs.sk

If we compare the baseline for 2010 to 2015, we can say that FDI flows to approximately the same number of sectors and the rest remain less represented by foreign investors. These are traditional foreign investors and countries of origin of FDI, which place their investments in traditional industries. These do not change significantly, and investors do not even change their behavior and go where they have the same background and fulfilled the economic and other conditions.

Large disproportions are also in the regional FDI deployment, essentially since the creation of the independent SR in 1993. If we come out from the available information (according to the NBS) we can state that the localization of FDI according to individual regions of Slovakia is markedly unilateral and unevenly distributed. In the 


\section{ENTREPRENEURSHIP AND SUSTAINABILITY ISSUES}

ISSN 2345-0282 (online) http://jssidoi.org/jesi/

2019 Volume 6 Number 4 (June)

http://doi.org/10.9770/jesi.2019.6.4(40)

analyzed period 2010-2015, the western Slovakia regions obtained most of the FDI and, for example, in 2014 it was up to $83.2 \%$ of all FDI in the SR. The highest share was recorded in the Bratislava region by $69.2 \%$, followed by the Trnava region with a share of $4.4 \%$, the Trenčiansky region with $5.6 \%$ and the Nitra region by $4.0 \%$. We can say that Bratislavský kraj strongly dominates throughout the period under review. In comparison to the other regions, it is caused by the best economic conditions, the relatively best-developed infrastructure, the availability of a workforce with a relatively high level of education and a suitable structure, such as, for example, the proximity of the Vienna Airport and many others.

Other regions have a much lower inflow of FDI and, for example, Central Slovakia gained only 8.4\%, of which Zilina region 6.6\% and Banska Bystrica region 1.8\%. Even smaller inflows were registered by the regions of eastern Slovakia, to which only $8.2 \%$ of all FDI was in total. According to individual regions, in Kosice region it was $6.6 \%$ and in the Presov region only $1.6 \%$. The causes are clear and the regions in Central and Eastern Slovakia belong to the least developed regions over the long-term and are significantly lagging behind the regions in the west of Slovakia. It is a state that does not significantly change.

On the basis of the previous investigation, we found (the second research question) that the entry of foreign investors can be influenced by the constant improvement of economic, legislative and other conditions. Also, the better the starting conditions in the region, the more FDI there. If suitable conditions are created (e.g. in the Bratislava region) also in terms of the structure and qualification of the workforce, it can attract foreign investors. Just a skilled workforce is becoming a problem in several regions, especially in those where the FDI are located in the automotive industry and related industries.

This makes it clear and the conclusion is that regions that are able to create better conditions and attract more foreign investors are more advanced and those with worse conditions are lagging behind in all areas. As in less developed regions, there are a number of disadvantageous long-standing factors that do not allow sufficient room for foreign investors to develop. These include, in particular, determinants conditioning the development of the investment environment, from macroeconomic conditions to less developed infrastructure or inappropriate workforce structure. Subsequently, they mean lower regional GDP growth, higher unemployment and insufficient room for foreign investors, and much more.

\section{Conclusions}

When comparing the FDI status and its role in the economy of Slovakia it can be said that obstacles have been overcome after the last global recession and that the entry of foreign investors has risen globally but also in Slovakia. This was also reflected in an increased inflow of FDI into the economy of Slovakia and reflected also in GDP growth and the reduction of unemployment. Negative seems to be its insufficient total volume to the total needs of the Slovak economy and especially the uneven entry into individual branches, but also in the regional location within Slovakia. Although it is welcome to enter industrial production, its unilateralism (especially in the automotive industry) is becoming a risk especially in situations such as economic and financial recessions. The largest investors are traditionally the Netherlands, Austria and Germany, which also included other countries in the analyzed period, South Korea, the Czech Republic and Luxembourg. The distribution of FDI from the regional point of view points to the tendency to enter the most developed regions in the west of Slovakia (especially in the Bratislava region) with built infrastructure and more favorable overall conditions compared to the regions in Central and Eastern Slovakia.

In conclusion, it is important to note that for the Slovak economy, an increase in the total FDI volume and its better sectoral and regional localization is important, with the aim of directing them to regions with high levels of unemployment, low industrialization and regions where unused production capacities are. 


\section{ENTREPRENEURSHIP AND SUSTAINABILITY ISSUES}

ISSN 2345-0282 (online) http://jssidoi.org/jesi/

2019 Volume 6 Number 4 (June)

http://doi.org/10.9770/jesi.2019.6.4(40)

\section{References}

Caves, R. E. 2007. Multinational Enterprise and Economic Analysis. Cambridge University Press. 3rd edition. 2007. 402 p. Online ISBN $9780511619113 \mathrm{https}: / /$ doi.org/10.1017/CBO9780511619113

Devízový Zákon. The full text of the Act of the National Council of the Slovak Republic no. 202/1995 Coll. of September 20, 1995 Foreign Exchange Act and the Act amending the Act of the Slovak National Council no. 372/1990 Coll. on offenses in the wording of later regulations (by the wording) [cit. 2016-11-08]. Available on the Internet: http://www.nbs.sk/_img/Documents/_Legislativa/_UplneZneniaZakonov/Z2 21995.pdf

Dudáš, T. 2010. Foreing Direct Investment on the Slovak Economy. Bratislava: EKONÓM, 2010. ISBN 978-80-225-3084-2

Dudová, I., Polónyová, S. 2017. Social Entrepreneurship: A Way Developing Social Innovation in Regions. (Web of Science). In: Current Trends in Public Sector Research: Proceedings of the 21st International Conference, Šlapanice. - Brno: Masarykova univerzita, 2017. - ISBN 978-80-210-8448-3. - p. 260-267.

Dudová, I., Stanek, V. 2016. Migration - a challenge or another global threat In: Proceedings of the IInd International Scientific and Practical Conference "Methodology of Modern Research, March 28-29, 2016 Dubai, UAE". - Dubai: ROSTranse Trade FZC company, 2016. - ISSN 2413-1032, p. $42-45$

Dunning, J. H. 2012. International Production and the Multinational Enterprise (RLE International Business). Routledge, 456 p. ISBN 1138007846,9781138007840

Fabuš, M. 2014. Foreign direct investment and its impact on the Slovak Republic's economy, Economic Annals-XXI. 9-10(1). pp. 42-45

Fabuš, M. 2015. Impact of foreign direct investment on unemployment development in selected regions of Slovak Republic, Economic Annals XXI. - ISSN 1728-6220 155(11-12): 63-66.

Fabuš, M. 2017. Current Development of Business Environment in Slovakia and Czech Republic, Entrepreneurship and Sustainability Issues 5(1): 127-137. https://doi.org/10.9770/jesi.2017.5.1(10)

Fabuš, M. 2017. Development of quality of the business environment in Slovakia, In: Modern science: 4th International multidisciplinary scientific conference on social sciences and arts SGEM 2017. Conference proceedings Volume V. - Albena, Bulharsko: SGEM, 2017. ISBN 978-619-7408-17-1. - ISSN 2367-5659, S. 305-310.

Fabuš, M.; Csabay, M. 2018. State aid and investment: case of Slovakia, Entrepreneurship and Sustainability Issues 6(2): 480-488. http://doi.org/10.9770/jesi.2018.6.2(1)

Ferenčíková, S. et al. 2013. International Business Expansion - Strategies, Partnerships, and Human Resources. Bratislava: Wolters Kluwer, 364 p. ISBN 978-80-8078-532-1

Kabát, L., Filip, S., Filipová, L. 2016. Safety Measurmment Peculiarities in Selected Countries, Journal of Security and Sustainability Issues 6(3): 343-356. http://dx.doi.org/10.9770/jssi.2017.6.3(2)

Gozora, V., Hudáková, M. 2014. Regional disparities of road transportation in Slovakia. In: Informacijni technologii, ekonomika ta pravo: stan ta perspektivi rozvitku: Materiali mižnarodnoj naukovo-praktičnjoj konferenciji molodich včenich ta studentiv, Černivci 3-4 kvitnya 2014: Vipusk 11. - Černivci: Bukovinskij universitet, pp. 139-147. ISBN 978-617-614-064-1.

Hardy, J., Sass, M, Pollakova Fifekova, M. 2011. Impacts of horizontal and vertical foreign investment in business services: the experience of Hungay, Slovakia and the Czech Republic, European Urbaan and Regional Studies 18(4): 427-443.

https://doi.org/10.1177/0969776411422618

Kováč, M. 2016. How to measure security of citizens In: Informacijni technologii, ekonomika ta pravo: stan ta perspektivi rozvitku: Materiali mižnarodnoj naukovo-praktičnoj konferencii molodich včenich ta studentiv, Černivci 14-15 kvitnja 2016 : Vipusk 13. - Černivci: Bukovinskij universitet, 2016. - ISBN 978-617-614-028-3, p. 250-253.

Krchová, H. 2018. New Approach to Innovation Projects. In: Nordsci conference on social sciences: Conference proceedings, Helsinki 17 19 July 2018. - Sofia: Saima Consult ISBN 978-619-7495-01-0, S. 183-190.

Lincényi, M., Fabuš, M. 2017. Economic trends of business actors on daily newspaper market: case of the Slovak Republic, Entrepreneurship and Sustainability Issues 5(1): 91-104 http://dx.doi.org/10.9770/jesi.2017.5.1(7) 


\section{ENTREPRENEURSHIP AND SUSTAINABILITY ISSUES}

ISSN 2345-0282 (online) http://jssidoi.org/jesi/

2019 Volume 6 Number 4 (June)

http://doi.org/10.9770/jesi.2019.6.4(40)

NBS. 2015. Methodical guidelines for compilation of annual reports on the state of foreign direct investment in the Czech Republic FDI (NBS) 1-01 and on the state of direct foreign investment FDI (NBS) 2-01 reported as at 31.12.2014. Available on the Internet: http://www.nbs.sk/_img/Documents/OHP/Metodika_2014.pdf

Siller, H., Cibák, L. 2016. Korruption und ihre gesamtwirtschaftliche Bedeutung, Kriminalistik, ISSN 0023-4699, 70(1): 50-55.

Stachová, K., Stacho, Z. 2017. Level of Focus of Organizations Operating in Slovakia on Flexible Organizational Structure, International Review of Management and Marketing. - Mersin: Cag University, ISSN 2146-4405. 7(1): 245-250.

Stachová, K., Stacho, Z 2016. The Orientation on Innovation is a Challenge for Organisations operating in Slovakia (Web of Science). In: Efficiency and Responsibility in Education 2016: Proceedings of the 13th International Conference, Prague 2 - 3 June 2016. - Prague: Czech University of Life Sciences Prague, ISBN 978-80-213-2646-0. - p. 518-525.

Shuyan, L., Fabuš, M. 2019. Study on the spatial distribution of China's outward Foreign Direct Investment in EU and its influencing factors, Entrepreneurship and Sustainability Issues 6(3):1080-1096. http://doi.org/10.9770/jesi.2019.6.3(16)

Táncošová, J., Slaný, A. 2004. Teoretické aspekty priamych zahraničných investícií. (Theoretical Aspects of Foreign Direct Investments) Ekonomický časopis. Bratislava: SAP, 1: 62-73. ISSN 0013-3035. UT WoS 000220045400004. Available on the Internet: https://www.sav.sk/journals/ekoncas/ekon2004_01.htm\#04

Táncošová, J. 2013. Foreign direct investment and their influence on the economic development of Slovakia, Economic Annals-XXI. Naukovij žurnal Ukrainy No 3-4(1): 31-34. ISSN 1728-6220 (print), ISSN 1728-6239 (online). Available on the Internet: http://soskin.info/ea/2013/3-4/zmist.html

Táncošová, J., Švecová, S. 2012. Investment Attractiveness in the SR and the Effect on Foreign Investors. In: Elektronický zborník vedeckých statí a posterov. Gyongyos: Karoly Robert Foiskola. pp. 1484-1488. ISBN 978-963-9941-53

Tvaronavičienè, M., Masood; O., Javaria, K. 2018. Preconditions of the Eurozone economic security: how to overcome liquidity risk and cost inefficiency in leading banks of UK and Germany, Polish Journal of Management Studies, 18(1): 418-427 http://doi.org/10.17512/pjms.2018.18.1.31

Statistics of the Balance of Payments https://www.nbs.sk/en/statistics/balance-of-payments-statistics/foreign-direct-investment

Statistical office of SR https://www.nbs.sk/en/statistics

Štatistický úrad SR.https://slovak.statistics.sk/wps/portal/ext/themes

UNCTAD. 2016. United Nations Conference on Trade and Development. World Investment Report 2016. Investor Nationality: Policy Challenges. Available on the Internet: http://unctad.org/en/PublicationsLibrary/wir2016 en.pdf

Zeibote, Z.; Volkova, T.; Todorov, K. 2019. The impact of globalization on regional development and competitiveness: cases of selected regions, Insights into Regional Development 1(1): 33-47. https://doi.org/10.9770/ird.2019.1.1(3) 


\section{Acknowledgements}

The paper is the output of a scientific project IGA no. 3/2017 „Development of international business and international management in the conditions of globalization"..(Funder: VSEMvs IGA VSEMvs, i.e. School of Economics and Management in Public Administration)
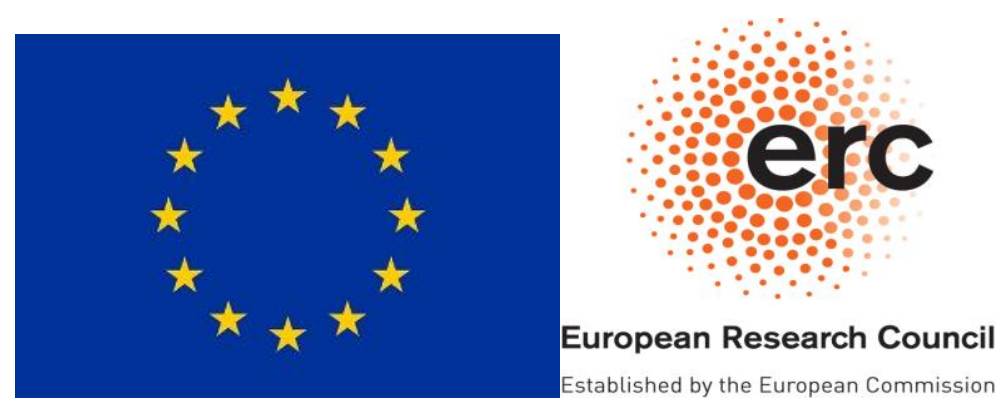

Judita TÁNCOŠOVÁ. Prof. Ing. PhD. is the Vice-Rector for Education an Profesor of Management in the School of Economics and Management in Public Administration in Bratislava. Special interest in International Economics Relation and Foreign Direct Investment. Her text book, monographs, scientific paper and article deal with the International business and management, microeconomic and macroeconomic problems.

ORCID ID: orcid.org/0000-0001-8963-6280

Copyright (C) 2019 by author(s) and VsI Entrepreneurship and Sustainability Center

This work is licensed under the Creative Commons Attribution International License (CC BY).

http://creativecommons.org/licenses/by/4.0/

\section{(c) (i) Open Access}

